\title{
REFORM OF THE LAW OF DOWER IN ALBERTA'
}

\author{
WILBUR F. BOWKER*
}

The main purpose of our Dower Act is to secture to the wife of a married person an interest in the family home by requiring her consent to a disposition and giving her a life estate on the husband's death. At the same time the purpose of our system of land titles is to enable those dealing with the registered owner of land to rely on the title. These two claims or interests of ten come in conflict. If, as Roscoe Pound says, the purpose of law is one of social engineering-to satisfy as many interests as possible with a minimum of friction-then it is proper to ask whether our Dower Act is good social engineering. When it was revised in 1948 everyone thought that in future no disposition of the homestead would, in any way, be null or void in the absence of consent. To the contrary the decisions now show clearly that every such disposition is entirely void unless, and until, followed by a new title. Consequently a purchaser, lessee or mortgagee may deal in the best of faith with the registered owner and yet acquire no interest in the land at all-and this in a province with a Torrens system. Perhaps one might suggest that we have not been very good social engineers, that we need a new lubricant to reduce the friction. The purpose of this paper is to propose several alternate oils for the machinery.

A passing reference must be made to common law dower-its was the wife's right on her husband's death to have assigned to her for life one-third of the lands he owned at death or had owned since marriage. The husband had a similar right extending to all the wife's land-this was tenancy by the curtesy. The 1833 Dower Act made several changes in the English law. Dower no longer attached to land the husband disposed of inter vivos or by will, but only to land of which he died intestate; however, it was extended to equitable estates owned by the husband at death. In 1925 both dower and curtesy were abolished in England.

In Canada all the older provinces but Quebec took the law of England as of their establishment and so inherited the common law rules on this subject. Dower still exists in all but Newfoundland. However, the husband, on purchasing land, can circumvent his wife's claim by one device or another. It is unnecessary to describe them here. Tenancy by the curtesy remains in all the eastern common law provinces except Newfoundland and New Brunswick (which abolished it as of 29th April, 1916) but seems to be of little practical importance.

Mr. Chitty has said of common law dower: "Dower, it may be safely said, is the last relic of feudalism. It is not only an anachronism but it is obsolete ... the best that can be said of dower is that it has a nuisance value."

"Wilbur Fee Bowker, Q.C., B.A., LL.B. (Alta.), LL.M. (Minnesota), Dean, Faculty of Law, University of Alberta.

1This is a paper delivered at the Annual Mecting of the Law Society of Alberta at Edmonton on 3rd February, 1960, with a few changes.

-6 Chitty's Law Journal 133 (1956). 
In the United States common law dower has been abolished in most states but in many it has been replaced by "homestead" laws. These vary in detail, one from another, but their usual features are: (1) the owner of the home cannot dispose of, or encumber, it without his sponse's consent; (2) the wife or family has the use of it after the owner's death; (3) it is exempe from sale under execution.

The western provinces have all borrowed from the United States laws of this general type. Our "Dower" Act is really a homestead act. As Egbert J. has observed, "There may be some who think that this is an import we could very well have done without." Yet there is an important social policy behind this type of legislation-to furnish a degree of security to the family.

In considering how better to accommodate this policy to that of the Torrens system it will help to look at the jurisprudence of the western provinces since they introduced homestead laws.

\section{ALBERTA}

The Northwest Territories took the law of England, as of 15th July, 1870, insofar as applicable. Thus common law dower as amended by the 1833 Act became part of the law. Then in 1886 Parliament passed the Territories Real Property Act, providing a Torrens system of registration of titles to land. The existence of common law dower has generally-been considered inconsistent with a land registration system for it imposes an invisible encumbrance on the title. Hence the 1886 Act abolished dower and curtesy as well. This remained the law when Alberta was created, and indeed until 1915.

In that year the legislature passed the Married Woman's Home Protection Act. In Overland v. Himelford, Ives, J. explained the reason and effect of the Act as follows:

"Previous to the year 1915, the people of this province had experienced a land boom, particularly in the cities and cowns, with all its attendant speculation. The wives in Alberta said, in effect, to the Legislature, where this speculation affects our homes we want it stopped. We have a home in the morning but it is sold or mortgaged at night. Our husbands may deal with their lands as they please subject only to their duty of providing us with a home which shall be placed beyond the risk of their speculation. These representations resulted in legislation in 1915 called The Married Woman's Home Protcetion Act, ch. 4. The name of this Act is very suggestive, although it created no right of property in the wife. It gave her only a right of filing a caveat which forthwith clouded the title, and prevented the husband from dealing with the land, in so far as registration was required, from the moment the caveat was lodged."

In 1917, it was replaced by The Dower Act. This gave her a life estate in the homestead arising on the husband's death and provided that any disposition made without the wife's written consent is "null and void". The requirement of a certificate of acknowledgment by the wife was in the Act from the beginning, and the alternate requirement of an affidavit by the husband that he is not married or that the land is not his homestead was added in 1919. From 1917 until today the courts and legislature and the legal profession too have wrestled with the question-what is the effect of a disposition of the homestead made without consent, properly given and executed?

In Choma v. Chmelyk" the husband sold the homestead under agreement for

BRobertson v. Robertson (1951) I W.W.R. (N.S.) 183.

${ }^{4}$ Re McLeod [1929] 3 W.W.R. 241 per Harvey, C.J.

s[1920] 2 W.W.R. 481.

'[1918] 2 W.W.R. 382. 
sale. The wife did not consent, probably tecause the parties did not know of the existence of the Act. Shortly after, husband and wife brought suit for a declaration that the agreement was null and void. Scott, J. held that it was not null and void but merely ineffective to put an end to the wife's potential life estate. Subject to this it was a valid and subsisting agreement. $\mathrm{He}$ was influenced by the fact that at common law a husband could sell his land, subject to the wife's inchoate dower rights; and he thought that the new "dower" has the same quality as common law dower. His view does not give due effect to the requirement of consent. Such a requirement is intended to give the wife a "veto" power. This decision really ignores that fact, and yet it has influenced profoundly our law on the subject.

Two years later, in Overland v. Himelford, the husband granted a lease of the home. The wife signed it as though she were lessor, but did not acknowledge her consent as required by the Act. Six months later the spouses brought action to avoid the lease. Walsh, J. held against them and the Appellate Division was equally divided. Stuart and Ives, JJ. thought the Act was intended to secure to the wife the enjoyment of the family home during even the husband's lifetime unless she consented to change it and that the proper interpretation is to hold the lease entirely void because she did not properly acknowlege her consent. ${ }^{8}$. This is the generally accepted view in Saskatchewan and Manitoba. Beck, J. with Harvey, C.J. concurring, said that where the husband makes a disposition without the wife's consent her estate is preserved, thus agreeing with Scott, J. in Choma. He held further that she might dispose of her dower interest. By signing the lease she had done so and no certificate of acknowledgment is required.

In the meantime, in 1919 the legislature had amended the Act to say that the disposition without consent was null and void only insofar as it may affect the interest of the said wife." Thus the view of Scott, J. clearly became law.

In 1926 the Legislature struck out of the Act the words added in 1919, restoring it to its original form. This left some doubt as to whether a disposition was now entirely null and void. ${ }^{10}$ In 1939 came Spooner v. Leyton." The husband entered into an agreement to sell the homestead and took an affidavit that it was not his homestead. In fact, the wife had refused to consent. She brought action for a declaration that the agreement was null and void and for possession. The Appellate Division held that the agreement was valid but was subject to the wife's possible life estate. The 1926 amendment of the section did not operate to render the disposition absolutely null and void. The judgment of Scott, J. in Choma was still applicable. Harvey, C.J. added that if the Legislature intended to make the disposititon completely void, "one would have looked for some such words as 'absolutely' or 'for all purposes'."

In 1942 the legislature added these words. Henceforth a disposition with.

\footnotetext{
iNote 5, supru.

"Stuart, ]. changed his mind in Johnson v. Johnson [1922] 2 W.W.R. 272.

'1919 c. 40. This amendment also said that execution by the wife of a disposition is a consent. Perhaps the legislature intended that executien need not be acknowledged as a consent but Reddick v. Pearson [1948] 2 W.W.R. 1144 holds that it must be.

10In Re Miller [1928] 3 W.W.R. 643 Walsh, J. held that the 1926 amendment made a disposition without consent absolutely null and void.

1'[1939] \ W.W.R. 734. aff'd. [1939] 2 W.W.R. 237.
} 
out consent was "absolutely null and void for all purposes." The consequence was that a husband wanting to avoid the disposition could set up the absence of consent by resisting an action for specific performance, ${ }^{12}$ or by bringing his own action. Reddick v. Pearson ${ }^{13}$ illustrates the operation of the amendment. Pearson gave to Reddick an oil and gas lease of part of his homestead. Mrs. Pearson signed the lease and a commissioner for oaths signed the certificate of acknowledgment. In fact, Pearson was present at the time and his wife did not actually give an acknowledgment. She did, however, admittedly approve of the transaction. Reddick made monthly payments of $\$ 100$ for seven months. Then the value of the oil rights increased. Both spouses successfully asserted that the lease was void. McLaurin, J. held that the wife's signature to the lease must be acknowledged just as a consent must be, and since the certificate of acknowledgment was untrue, the lease was void.

It is likely that this case was overtuled by McColl-Frontenac Oil Co. v. Hamilion. The facts were very similar. The only possible flaw was the husband's presence when his wife acknowledged. Howson, C.J. believed the evidence that Hamilton was present and held that the wife's consent was ineffective. On appeal, the court was evenly divided, but only on the finding of fact that the husband was present. The Supreme Court of Canada ${ }^{14}$ upheld the oil lease, basing its judgment on section 9 , a curative provision that so far as I know was never before considered, though it had been in the Act since 1919. It said that where the wife has given her written consent to a contract "for the sale of property" and the consideration has been partly performed by the purchaser, she shall, in the abserce of fraud by the purchaser, be deemed to have consented to the sale in accordance with the Act. The Hamiltons did not allege fraud. The Court held that the oil lease was a sale of property and section 9 applied, thus curing the defect in the consent. One welcomes a curative section in these circumstances, but the Supreme Court had to go to some lengths to apply section 9 to an oil lease. There is force in the dissent of Kerwin, J. that it applied only to an ordinary sale that can be followed by a transfer. In any case, section 9 was omitted from the new Act in 1948, obviously because it was considered unnecessary. In light of the decisions since, one might wish we had a much broader curative provision than section 9. Section 6 (3) is the nearest approach to one in the present Act. It permits a judge to authorize registration of a disposition though proof of execution of consent or of the making of an acknowledgment is defective if he finds that the consent was executed or that acknowledgment was made. Its scope is very narrow.

The cases that brought about the repeal of the old Act were Essery v. Essery and Tatko v. Leifke, decided together in 1947. In each case the husband sold the homestead ard in executing the transfer took the statutory affidavit that he had no wife. In Tatko the transfer was registered and later a further transfer was registered while in Essery the original transfer and a further transfer were registered together. Even in the latter situation the Appellate Division held that the second transfer was not void and the widow

12Dach v. Bochan [1948] 1 W.W.R. 622. That case holds that even an executor can resist an action for specific performance where the widow did nct consent.

1:[1948] 2 W.W.R. 1144.

1+(1951) 4 W.W.R. (N.S.) 77, (1952) 5 W.W.R. (N.S.) 1, [1953] I S.C.R. 127. 
could not set it aside. ${ }^{15}$ It might be noted that the curative provision, section 9, was inapplicable here because it applied only to a faulty consent or acknowledgment and not to a false affidavit.

These judgments were delivered on December 11, 1947. My memory is that the Law Society of Alberta or local bar associations or both recommended that the Dower Act be revised to provide that agreements for sale no longer be null and void if made without consent duly given but that on registration of the transfer the wife be given an action against the husband for half the purchase price. I do not recall what recommendation, if any, was made for the case of a mortgage, lease, or other disposition. In any event, a new Act was assented to on March 31, 1948. The explanatory note says:

"The Land Titles Act was passed to give certainty to title to estates in land and to facilitate the proof thereof. The former Dower $A c t$ partially defeats the purpose of the Land Tikles Act by giving rise to uncertainty to title by creating an unregistered incerest in land which frequently cannct be discovered and which may override a title obtained on reliance upon the register. The courts have had to deal with numerous cases on The Dower $A c t$, many of which arose due to the conflict in principle between it and The Land Tilles Act.

"The reason for the conflict between the two Acts was the provision that a transfer of a homestead made without the wife's consent was null and void for all purposes. The principal change made in the new Act is that the section making such a transfer null and void for all purposes is removed, thereby removing the conflict with The Land Titles $A c t$.

"In lieu of making such a transfer null and void for all purposes, such a transfer is prohibited under penalty.

"Under the old Act the wife had a right of action to have the land taken away from the first purchaser under such a transfer and revested in her husband, and the first purchaser had a right of action against the Assurance Fund for damages for the loss of the property purchased by him.

"Under this Act the first purchaser obtains a valid title. Accordingly, the wife has no right of action to have the land revested in her husband. Instead of this the wife is given a right of action against her husband for her loss which is fixed by the Act at one-half the value of the property transferred without her consent. If the judgment against her husband is unsatisfied she may recover the amount of the judgment from the Assurance Fund."

The important point to note is that the Act still prohibits dispositions without consent and indeed goes further by imposing a penalty on the married person who makes such a disposition. Then it provides that the land ceases to be the homestead when a transfer by the married person is registered and thereupon the transferor is liable to his spouse in an action for damages in the amount of one-half of the consideration or value of the land. If the judgment is not paid recourse may be had to the Assurance Fund. Another change is a provision giving dower rights to a husband where the wife owns the homestead.

It was not long before queries were raised as to the effect of a sale made without a validly executed consent and objected to by the spouse or even by the vendor before registration of a transfer, and as to the validity of a mortgage, lease, oil lease, or easement. It is quite clear that these are all dispositions, but are not followed by the issue of a new title so the spouse never can have an action for half the purchase price.

The cases that have come before the courts are those of an agreement of sale, where the spouse objected before the time came to give a transfer. The first is Pinsky v. Wass." In one transaction Pinsky agreed to sell his home to Wass and Wass agreed to sell his to Pinsky. Both husbands and their wives signed the document. No proper dower consent was executed by anyone. Soon after they moved the Pinskys regretted the exchange and brought action

${ }^{10}[1947] 2$ W.W.R. 1044.

10[1950] 2 W.W.R. 1278, (195I) 2 W.W.R. (N.S.) 49, [1953] I S.C.R. 399. 
to have it set aside. It turned out that Mrs. Pinsky was the owner so Pinsky raised the absence of his consent, under the Dower Act. The trial Judge, McLaurin J., held that nothing in the Act suggests that the purchaser's title is infirm because of lack of consent by the vendor's wife: "having regard to the antecedent legislation repealed by this statute it is reasonable to assume that the legislature desired to get rid of the recurring circumstances where a purchaser's title in a bona fide transaction was completely bad." Absence of the statutory consent is not a ground for setting the transaction aside. However, he found for the plaintiffs on an "escape clause" in the agreement. On appeal, O'Connor, C.J.A. would have upheld the trial judge but did not find it necessary to consider the Dower Act. W. A. Macdonald, J.A. attached great important to the prohibition of disposition without consent and to the penal provision. Each disposition was made in violation of a statutory prohibition and hence is unlawful and void and can confer no rights on either party. "In such a case the court leaves the parties in the situation in which it finds them." In this view the result would be that the Pinskys could not have the agreement set aside and Wass could not get specific performance. Parlee, J.A. with Frank Ford, J.A. concurring, agreed with the view of the trial judge that the agreement was not completely bad. He does not specifically say that the Pinskys might have avoided the agreement had they acted otherwise than they did but he so implies, for he says there was either a consent or waiver or estoppel. Clinton Ford, J.A. thought the agreement was invalid but that the Pinskys were estopped from serting up the non-compliance. Since a majority held the escape clause inapplicable the Wass appeal was allowed and specific performance granted. The Pinskys appealed to the Supreme Court, and succeeded under the escape clause. However, the views of Estey, J. (Kerwin J. concurring) on the Dower Act are of interest-"This direct prohibition, together with the provision for a penalty makes the agreement legally unenforceable at the instance of the married person;" It is voidable at the instance of the spouse, Pinsky, and on the facts he is not estopped from asserting his rights. Kellock, J. (Locke J. concurring) held that the Pinskys could not invoke the Dower Act because Pinsky contracted as owner, and his wife by signing the document was undertaking to do whatever would be necessary to enable him to convey. In this view, no question of his dower rights is involved. It is perhaps fair to say that this case left remaining doubts as to the effect of the statute.

The second case is Meduk v. Soja. ${ }^{17}$ Mrs. Meduk owned the home and entered into an informal agreement with the Sojas to sell for cash. When the real estate agent asked Meduk to sign he declined, saying it was not his property. He never execured a consent under the Dower Acr. The Sojas took possession but a month later Mrs. Meduk notified them she was rescinding the agreement because they had not paid the purchase price. They then tendered the price which was refused. Soon after Mrs. Med:ık took proceedings for possession. The Sojas counterclaimed for specific performance and Mrs. Meduk then raised her husband's refusal to sign a consent under the Dower Act. (Her husband was added as a party when the case was in the Appellate Division.) 
The trial judge said: "I hold that this was a voidable agreement and that the plaintiff is estopped from denying the validity of the agreement in favour of the defendants, who are innocent purchasers. It would be inequitable to assist the plaintiff in avoiding specific performance of the agreement and her reliance on the Dower Act was a patent attempt to escape liability." Mrs. Meduk's appeal failed and she appealed to the Supreme Court. An unanimous judgment allowed her appeal. There was no contract in existence. Even if estoppel is available to the purchaser, which was not decided, there is no estoppel on the facts. Meduk's various actions indicating assent to the sale do not estop him from saying he did not consent in writing.

This judgment shows that a sale without consent is void. At least it is void until a transfer is registered. The history of the Alberta Dower Act, fortified by the explanatory note quoted above shows that this is not what the legislature intended; and nearly all the Alberta judges ${ }^{13}$ in Pinsky and Meduk, knowing the backgrourd declined to hold the sale void. However, the Supreme Court looked at the prohibition against dispositions without consent, supported by a penalty of fine or imprisonment and concluded the disposition is void. It is easy to point out that during the many years when the Act said the disposition was null and void, it was not, and now when the Act no longer says it is, it is. One may perhaps say with the benefit of hindsight that the Act might have been better framed.

The latest case is Shopsky v. Danyliuk."' Shopsky transferred the home. stead to himself and the defendant jointly. He took the statutory affidavit that he was not married and the transfer was registered. He and his wife then brought action for a declaration that the transfer was void. Milvain, J., held that it was. He referred to the provisions in the Act giving the wife an action against her husband for damages of half the consideration or value once the transfer has been registered, but held that it did not prevent the wife, and seemingly the husband who has committed perjury, from asserting that the transfer is void. With respect, this appears to give no effect to section 4 (2) which says that land ceases to be the homestead when a transfer is registered. The Act was intended to make the first transfer indefeasible and to convert the wife's right to refuse consent into an action against her husband for damages. Milvain, J., thought that if this was the intention the legislature could have said so. The suggestion made here is that the legislature did say so.

I know of no case under the 1948 Act dealing with a mortgage to which valid consent has not been given. During the many years when the disposition was good except in relation to the wife's potential life estate, it is clear that the mortgage was effective as against the mortgagor. ${ }^{20}$ After the 1942 amendment and under the 1948 Act the question properly arises-can the wife obtain a declaration that the mortgage is entirely void? -or even, can the mortgagor himself? Probably a court would go to great lengths to avoid either result,

18W. A. MacDonald, J.A., in Pinsky is the exception. In Shopsky v. Danyliuk, note 19 infra, Milvain, J. thought that every contract expressly prohibited by statute in void and that the "null and void" provision was omitted from the 1948 Act as surplusage.

10(1959.60) 30 W.W.R. 647. An alternative ground of the judgment is that the transferee knew Shopsky was married and therefore her title is tainced with fraud. This is one of the exceptions to indefeasibility under the Land Titles Act, and this ground of the decision is not the subject of my criticism.

${ }^{20}$ Royal Bank v. Wallsmish [1945] I W.W.R. 713 at 717. 
but one cannot be sure. Certainly in Reddick the lessor and in Pinsky and Meduk and Shopsky the transferor seemed to have a status to impeach his own transaction. In Parslow v. Moore, ,1, Walsh, J., dealt with a mortgagor's argument that the mortgage was completely void because his wife's consent was defective. (He knew it was for he procured it.) In the strongest language His Lordship said that in the circumstances the husband would be estopped even if the statute said the mortgage was complete void.

Another question is whether a purchaser, prior to registering title, could rescind the agreement. This suggestion may seem startling but if the transaction is void, he should be able to raise want of title in his vendor, unless perhaps he was fraudulent. There is as yet no direct authority on this point nor on the analogous situation of a lease, oil lease or easement.

This summary of Alberta law on the absence of a properly executed consent is designed to show that the effect of the present Act is not what it was intended to be; that the conflict in policy between the Dower Act and the Land Titles Act is unabated: and that the Dower Act should be changed.

It will help at this stage to see what we can learn from the laws of Saskatchewan, Manitoba and British Columbia, since all these provinces (and no others) have "homestead" laws, more or less like Alberta's.

\section{SASKATCHEWAN}

Saskatchewan's Homesteads Act was originally passed in 1915. It never has in terms given the wife a life estate in the homestead. An obscurely worded provision (sec. 12) gives her the right to stay in possession or to the rents and profits if necessary for her support."

Apart from this the wife's rights are purcly negative-to prevent disposition by withholding consent. Yet it has been held, contrary to the jurisprudence of this province, that if the husband is in possession of a homestead when he makes a disposition without her consent, she is entitled to an order for possession. ${ }^{23}$

The requirements for consent (sections 4 and 5) are similar to those in Alberta except that the wife's consent is called an acknowledgment, and the officer who takes the certificate of acknowledgment is disqualified if he prepared the document or is otherwise interested in the transaction.

Th Act has never clearly spelled out the consequences of a disposition made without a valid acknowledgment and certificate. It has never said that it is "null and void" or "invalid". There was for years doubt as to whether it was void or voidable, but the courts have never suggested that it is valid subject to her life estate. As already stated, the Act gives her none. However, one important difference from our law is that since 1948 we have had no curative provision." Saskatchewan's curative section, $7(3)$, says that the person taking the disposition is not bound to inquire whether the facts alleged in the husband's affidavit (that the land is not a homestead or that he has no

\footnotetext{
21[1930] 2 W.W.R. 340.

"2E.g. Re Wenet [1949] 2 W.W.R. 85.

n3E.g. Audoorn v. Audoorn [1935] 2 W.W.R. 362.

2'Sec. 6 (3) can be ignored. Even the old Sec. 9 (1) applied in McColl Frontenac Oil Co. v. Hamilion was much nartower than Saskatchewan's Sec. 7 (3).
} 
wife or that his wife has not resided in the province since the marriage) or in the certificate of acknowledgment are true, and an instrıment purporting to be completed according to the Act is valid and binding save as provided in section 11. Section 11 says that knowledge by the grantee that the land is the homestead of the grantor and that he has a wife whose consent is required but who is not a party to the instrument is fraud, and the wife may have the instrument or title issued thereon set aside.

The cases on the curative provisions can be divided into two groups (1) those where consent or acknowledgment was not properly given; (2) those where a false affidavit was taken.

Irregularities in the consent or certificate, no matter what they be, are almost sure to be cured by section 7 (3) as long as the wife signed her consent and a certificate of acknowledgment was given even though improperly unless, of course, there was knowledge ty the grantee. Thus a purchaser has been granted specific performance where the wife gave her consent before a dis. qualified person."

A more difficult problem faced the court in Bonkonski v. Rose." The husband gave an oil lease and the lessee procured the wife's acknowledgment in blank. The lessee then obtained the signature of a qualified officer to the certificate of acknowledgment though in fact the officer never saw the wife. Later the lessee assigned the lease to an oil company which had no knowledge of the irregularities.

The question was whether the assignec can invoke the curative provision. Procter, J.A. held that on a proper construction of the relevant sections the curative provision protects only the person who took under the original disposition and not an assignee from him. Space does not permit an examination of this contention but it seems to me to be sound. Proctor, J.A. also held that previous decisions show the disposition to be void rather than voidable so that the assignee is in no stronger a position than the assignor.

However, the majority held that the curative sections extend to the assignee.

In the subsequent case of Prudential Trust Co. v. Forseth the Supreme Court considered a number of objections to a disposition of minerals, including the argument that the acknowledgment and certificate were not properly given because they did not describe accurately the actual disposition. The Court held that these irregularitics did not mislead the wife. The important part of the judgment is that which approves of Bonkowski in holding that an assignee can invoke the curative section."

The lesson we can take from these last two cases is this. If a curative provision is desirable it will be important to determine as a matter of policy whether its protection should extend to an assignee and then to frame a provision that leaves no doubt.

The leading case of Friess v. Imperial Oil deals with a forged consent. The husband gave an oil lease. As his wife was sick, the lessee's agent had the lessor's daughter sign her mother's name and had a Justice of the Peace sign the certificate. He never saw the wife. Three years later when a better offer

${ }^{25}$ Lavoie v. Marchildon (1953) 9 W.W.R. (N.S.) 263.

sti(1955) 16 W.W.R. 481.

27 [1960] S.C.R. 210 at 221-23. 
was made the wife brought action. The lease was set aside. "The authoritics establish that the object of the Act is to prevent the husband from alienating the homestead without the consent of his wife and, in my opinion, it is clear that as against a non-consenting wife every transfer, agreement for sale, lease or other instrument intended to convey any interest in a homestead is invalid and void." The court rejected the defendant's argument of estoppel. Assuming the wife could ratify, she did not. The defendant is bound by its agent's knowledge of the facts and this knowledge is fraud under section 11.

Coming now to the second group of cases, where the husband has taken a false affidavit, a number of judgments deal with affidavits that the land was not the homestead. In Farmer's Mutual Petroleum v. Jackson ${ }^{29}$ the disposition was a transfer of minerals. The husband thought "homestead" meant land he had homesteaded. The purchaser's agent knew he was married and even had been in his home. The trial judge found the agent had knowledge it was the home and set the transaction aside. This was sustained on an equal division in the Court of Appeal.

The Supreme Court dealt for the first rime with the case of a false affidavit in Prudential Trust Co. v. Olson, decided at the same time as Forseth. The original grantee assigned to Canadian Williston Petroleums, a bona fide purchaser. Martland, J. for the Court held the assignee was protected by the curative section."

\section{MANITOBA}

In Manitoba, common law dower was abolished in 1885, but in time pressure came for a homestead law. Accordingly, the Dower Act was passed in 1918. Like Alberta's it applies equally in favour of husband and wife, but for convenience I shall speak of the wife's rights. She is given a life estate in the homestead, but the Court of Appeal in Crichton v. Zelentisky $y^{31}$ said that it is not actually vested in her on the husband's death but only when the executor conveys it to her and in the meantime she may not enter on the land. The same case held that the life interest is not exempt from her late husband's creditors. Certainly the first holding is not correct for Alberta. As for the second, her life interest is protected in Alberta as against exccutor creditors but seemingly not as against ordinary creditors."

A disposition without her consent "shall be invalid and ineffective" and the requirements of a formal consent and certificate of acknowledgment are much like those of Alberta and Saskatchewan. Similar too, is the requirement that the grantee take an affidavit that he has no wife or that the land is not the homestead. In addition, there is the novel requirement that where the wife consents the husband must take an affidavit that the consenting woman is, in fact, his wife. In other words, an affidavit is needed even when the wife gives her consent. This has no counterpart in Alberta or Saskatchewan.

The curative provisions are, of course, important. A certificate of acknowledgment is conclusive evidence of the truth of the statements therein except as

28 (1954) 12 W.W.R. 151 at 155.

20(1956) 19 W.W.R. 625: compare Re Scott [1942] 2 W.W.R. 485.

30[1960] S.C.R. 227 at 232-34.

31[1946] 2 W.W.R. 206.

s2Compare Re Conlin (1914) 7 W.W.R. 187 with Re Ferguson (1957) 23 W.W.R. 521. 
against a grantee with actual knowledge of their untruth, (section 8 (4)) and an affidavit is valid except as against a grantee with actual knowledge of untruth or who is fraudulent, and there is no duty to inquire as to the truth of the affidavit (section 8 (7)). In principle these curative sections are similar to those of Saskatchewan.

There have been a number of cases in which the grantee has invoked these provisions, and where the disposition has been followed by a new title the grantee has the benefit of the various "conclusive" provisions of the Real Property (Land Titles) Act. An early case points out that where the transferor swore the land was not his homestead and the wife later alleged the transferees know it was, the burden is on her to prove actual knowledge, ${ }^{, 33}$ and the case is the same where a mortgagor swore he had no wife and there was no suggestion that the mortgagee knew he did."

Manitoba, like Saskatchewan, has had to consider the case of a forged consent. The difficult question is whether the wife is bound where the grantee has acted in good faith. In other words, does the rule that a grantee must be sure of the identity of his grantor apply in favour of the wife? In Chudyj v. Canada Permanent Loan Corp." the husband forged the wife's signature and the commissioner for oaths, who was agent of the mortgagee, quite improperly took the certificate of acknowledgment though the wife had never appeared before him. The mortgagee foreclosed and then the wife brought action. By a majority of three to two the Court of Appeal held that the company was not affected by its agent's fraud because in falsely signing the certificate he was acting as a public official and not as agent. The majority were clearly influenced by the seriousness from a mortgagee's standpoint of holding a mortgage void in these circumstances. One of them, Richards, J.A. said:

"It should be borne in mind that there was no provision for dower in Manitoba priot to 1918, and that, when the legislation was introduced, the dangers and troubles of it were considered. Tht Legislature then clearly endeavoured to protect innocent purchasers. In doing so it provided drastic safeguards. The protection given bona fide transactions by $T$ he Dower $A$ ct is, in some respects, much greater than is given by The Real Property Act, 1934, ch. 38, which does not protect persons who rely on instruments which are discovered later to be forgeries. The case of Gibbs v. Messer [1891] A.C. 248, 60 L.J.P.C. 20, and following cases do not apply to The Dower ACl."

The dissenting judges held that the provision curing defective acknowledgments does not apply where the wife did not sign the consent. They were also prepared to impute the knowledge of the agent to his principal. In this type of case it seems proper to do so; to protect the principal seems unjust.

In Manitoba where the disposition is "invalid and ineffective" the same question can arise as under a statute where it is void-viz. can the grantee invoke the non-compliance as well as the grantor's wife? Considering the purpose of the Act, one is inclined to answer no because the Act is for the benefit of the wife. On the other hand, if the transaction is regarded as void, not merely voidable, then there is no contract and either party can invoke the fact. In Wall v. Dyck" neither party to the agreement for sale thought of the Dower Act. The buyer, wanting to escape, notified the vendor who quickly

a3McKinnon v. Smith [1925] 3 W.W.R. 290.

a4Reep v. Shucketl (1955) 15 W. W.R. 375.

95 [1937] 2 W.W.R. 225: compare Friess v. Imperial Oil note 28 supra.

30IV all v. Dyck [1950] 1 W.W.R. 699. 
produced his wife's consent. The Court of Appeal held he was too late. In Saskatchewan, on the other hand, a seller has been allowed time to produce his wife's consent. ${ }^{37}$ This seems fair, but if correct, means the transaction is voidable rather than void. A related question is that of a buyer (or seller) who deliberately enters into an agreement knowing the Act has not been complied with and then brings action to have the agreement declared void. Can he be met with the defence that he does not come into court with clean hands? These questions, and indeed the whole scope of estoppel, have not been worked out in any of the prairie provinces.

The Prudential Trust Company has made its contribution to the law of dower in Manitoba as in Saskatchewan. The case is Brown v. Prairie Leaseholds $L t d^{38}$ The transaction was of a type now familiar but the farmer and his wife did not wair long to take proceedings. As is so often the case there was a sharp dispute as to the facts. The trial judge believed the plaintiffs and found that the documents were not completely filled out when the wife signed her consent and gave her acknowledgment to the commissioner who was the grantee's agent. The trial judgment seems to say that there was no contract at all because the document indicated a disposition different from the one Brown thought he was making, but the judgment then speaks of the contract being induced by fraud and then holds that the farmer's subsequent acts did not constitute an affirmation.

The violation of the Dower Act was an alternate ground of the decision. The wife signed voluntarily but she did not consent to all the dispositions in the documents; she thought she was consenting to much less and on her part it is non est factum. It was found too that she did not sign "apart from her husband" and that this requirement is as strict as the requirements of the Wills Act. The curative clause did not help the company because its agent took the acknowledgment. The company invoked Chudyj for the proposition that its agent in so doing was a public officer. The court held that nevertheless he was the company's agent immediately before and after, and his knowledge of untruth of the certificate was the company's knowledge. This seems sound. If a purchaser uses its agent as a commissioner to take acknowledgments, then his knowledge of the untruth of a statement in an acknowledgment should be attributed to the principal. The Court of Appeal dismissed the appeal without reasons ${ }^{310}$ and in refusing leave to appeal to the Supreme Court of Canada" said that the question of the wife's consent under the Dower Act "is only of academic importance if the said transfer and assignment were fraudulently obtained, as found by both courts."

\section{BRITISH COLUMBIA}

The last province to examine is British Columbia. Common law dower, as modified by the provisions of the 1833 Act persisted until 1925 when it was abolished. Then in 1948 the Wife's Protection Act was passed. Its most significant feature is that it applies in favour of a wife only after she has filed an "entry" in the Land Registry (Land Titles) Office against the homestead.

\footnotetext{
3iE.g. Neilsen v. Jenewein [1924] 2 W.W.R. 696.

${ }^{38}(1953) 9$ W.W.R. (N.S.) 577.

39(1954) 12 W.W.R. (N.S.) 464.

40(1954) 13 W.W.R. (N.S.) 40.
} 
This entry is analogous to a caveat by a wife under the prairie Acts but differs in that she has no life interest in the homestead without it.

When she has made entry she is entitled to a life estate in the homestead, and every disposition "shall be null and void for all purposes unless made with the consent in writing of the wife." The formalities of consent and certificate of acknowledgment are similar to those of the other provinces. Many of the provisions seem to be taken from the Alberta Act as it stood just before 1948. The curative provision (section 10 (1)) is almost identical with our old section 9 save that it is confined to a "sale of the homestead" (instead of "sale of property") and thus would perhaps not cover an oil lease. Needless to say there is no provision for an affidavir by the husband that he has no wife or that the land is not his homestead. Under British Columbia's scheme such affidavits have no place. The existence of the entry is notice to all that the land is the homestead and that the owner has a wife. To date, most of the cases have been over the issue of removing the entry or dispensing with consent and need not be noted.

In one case the wife made entry after her husband had made an agreement for sale. It was held her entry was too late. The Act renders void dispositions made after entry, not before, so the entry must be discharged." In another case the husband secretly sold the homestead. After the conveyance was registered the wife brought action to have the sale declared void. The buyer had acted bona fide so obviously the wife could not succeed." These are the only reported cases where the wife has challenged a disposition. In time cases will doubtless arise where a wife will allege she did not know what she was consenting to, or that her husband was in the room. The curative section will cover these cases.

\section{CONCLUSION}

The question now must be asked-what should the law of Alberta be? In answering this, we should keep in mind these considerations:

1. The importance from a social standpoint of the wife's claim to some form of control over and interest in the home.

2. The principles of the Torrens system and the interests of a grantee.

3. Other things being equal, the desirability of making such changes in a framework for which we, in this province, are accustomed.

4. The desirability of reducing the inconvenience and uncertainties in conveyancing.

The following alternatives emerge.

First:

to abolish the need of consent. The main arguments in favour are (1) it would simplify conveyancing, reduce litigation and remove uncertainties; (2) the purpose of homestead laws is largely served by the Family Relief Act. As against this, the Family Relief Act will not protect a widow whose husband has transferted all his property and it does not give her any direct control over the home. There is a growing acceptance of the idea in England that the wife should have some kind of a claim to the home, and New Zealand has a Joint

1'Linton's Case (1951) 3 W.W.R. (N.S.) 509.

1"Rousseall v. Rousseau (1956) 19 W.W.R. 237. 
Family Homes Act. ${ }^{\text {4: }}$ We have given the wife homestead rights for forty years and on the balance many consider they should be preserved.

\section{Second:}

to adopt a plan like British Columbia's that gives homestead rights when the wife files an entry and not otherwise. This certainly is simpler than our system and it gives third parties notice of the wife's claim. The only disadvantage is that wives may not know of their right to file an entry or may be reluctant to file.

\section{Third:}

to bring our Act into line with those of Saskatchewan and Manitoba. This means that the cumbrous conveyancing remains but that there is a fairer balance between the interests of wives and third parties. A curative section carefully drawn in the light of the decisions in those provinces will reduce almost to zero the possibility that a bona fide grantec will find his interest is in jeopardy, though it is no guarantec against litigation on matters of fact.

One might advance as a fourth possibility a return to our law as it stood prior to 1942-that the consent be required but that the only consequence of an improper disposition is to preserve the wife's life interest. This would have the virtue of disabling a grantor from impeaching his own transaction. On the other hand, it reduces the power of his spouse to prevent a disposition and this is one of the main purposes of homestead legislation.

As a fifth suggestion one might propose community of property. I know little of the subject, but am not inclined to exchange known terrors for unknown. We might find that such a drastic change would be equivalent to throwing out the baby with the bath-water.

Assuming we retain a statute basically the same as our own but altered along the lines of British Columbia's of Saskatchewan's and Manitoba's then a number of subordinate questions should be considered. The length of this paper precludes discussion but I shall set out those that occur to me.

1. Should the husband continue to have dower rights? (My opinion is no.)

2. Should dower rights continue to include a life estate in chattels? (section 2 (b) (v)

3. Should a court have power to order partition or sale of a jointly-owned homestead? ${ }^{\text {th }}$

4. Should a spouse who has released dower rights without consideration be able to change her mind as at present? (secs. 8 and 9)

5. Should a disposition be void where the consent is annexed to the instrument

8:See Macdenald, Observations on the L.and Law in the Common Law Provinces of Canada, 197 nt 220, in Canadian Jurispurdence (ed. McWhinney) (1958); Milner, Beneficial Ownersh:p in the Finmily Home: Recent Trends in the Britisls Commonwealth, 37 Can. Bar Rev. 473 (1959); Compare Thompson v. Thompson (1961) 26 D.L.R. (2d) I (S.C.C.).

11Robertson v. Robertson (1951) 1 W.W.R. (N.S.) 183 says there is no power; contra, McWilliam v. McWilliam (1960) 31 W.W.R. 480. The latter case holds that an order for sale under the Partition Act is not a disposition under the Dower Act. Sec also Fritz v. Fritz [1950] 1 W.W.R. 446, 1105, (1951) 4 W.W.R. (N.S.) 650 (Man.); Evans v. Evans (1951) 1 W.W.R. (N.S.) 280 (B.C.).

$M c W i l l i a m$ went to the Appellate Division which found it unnecessary to decide whether Robertson was correctly decided: (1961) 34 W.W.R. 476. 
and the spouse has omitted to sign the instrument though she has signed the consent? to $^{\text {to }}$

6. Should the spouse's potential life estate be assignable by him or within reach of his creditors? It may be now. ${ }^{40}$

7. Should the vested life estate be exigible under execution or subject to sale for ordinary debes? ${ }^{17}$

8. Should the action for damages by the spouse be retained-and the claim against the Assurance Fund?

9. Should it be possible for homestead rights to exist in more than one home, as at present?

In conclusion I trust that those interested in law reform will be persuaded that any one of my three proposed oils will reduce the squeaks in the social and legal mechanism.

1"In Reynolds v. Ackerman, 1953. reported (1960) 32 W.W.R. 289, McBride, J. lseld it is under sec. 5 (5).

10I have been told of an instance in which the spouse made an assignment for the benefit of creditors and the assignee filed a caveat against the homestead thus rendering difficult a sale by the owner. In Proskurniak v. Sawchuk (1959-60) 30 W.W.R. 407, Smith, J. held that the execution creditor of the apouse may properly file against the homestead a caveat covering the writ of execution. In an unreported judgment the Appellate Division set aside the eaveat on the narrow ground that it did not properly set out the interest it purported to proteet.

${ }^{17}$ At present it is protected ngainst execution creditors but paradoxically not against ordinary creditors: Re Ferguson (1957) 23 W.W.R. 521 , 